\title{
Efek Penambahan Tepung Daun Sirsak (Annona muricata L) dalam Ransum Berbasis Jerami Padi Fermentasi terhadap Kecernaan Bahan Kering dan Bahan Organik secara In Vitro
}

\author{
Effect of Addition Soursop Leaves Flour (Annona muricata L) in Ration Based on Fermented \\ Rice Straw on Dry and Organic Matter Digestiblity in In Vitro
}

\author{
N. Suningsih dan Sadjadi \\ Program Studi Peternakan Fakultas Pertanian Universitas Musi Rawas \\ Jl. Pembangunan Komplek Perkantoran Pemkab Mura Kelurahan Air Kuti, Musi Rawas \\ Corresponding email : ninings412@gmail.com
}

\begin{abstract}
This study aimed to determine and examine the effect of the addition of soursop leaves flour in fermented rice straw-based rations on the digestibility value of dry and organic matter conducted by In Vitro. The design used was a completely randomized design (CRD) consisting of 4 treatments and 4 replications. The treatments tested consisted of: $\mathrm{P} 0=$ basal ration, $\mathrm{P} 1=\mathrm{P} 0+$ Soursop leaves flour $1 \%, \mathrm{P} 2=\mathrm{P} 0+$ Soursop leavesflour $2 \%, \mathrm{P} 3=\mathrm{P} 0$ + Soursopleaves flour 3\%. Basal ration consisted of 45\% fermented rice straw, Mini Elephant Grass 30\%, bran $10 \%$, coconut cake $10 \%$, milled corn $4 \%$, and Premix $1 \%$. Variables observed were dry matter digestibility (DMD) and organic matter digestibility (OMD). The data obtained were analyzed using Variance Analysis followed by Duncan's Multiple Range Test (DMRT). The results of the study of the addition of soursop leaves flour in fermented rice straw-based rations had a significant effect $(\mathrm{P}<0.05)$ on DMD and OMD. The highest DMD and OMD values were shown by the treatment of P3 (3\% Soursop leaves flour) respectively which were $60.43 \%$ and $61.76 \%$. The conclusion of this study is the digestibility value of dry matter and organic matter increases with the higher addition of soursop leaves flour in the ration. The addition of soursop leaves flour in fermented rice straw-based rations did not have a negative impact on the digestibility of dry matter and organic matter and could be added up to $3 \%$ in the ration.
\end{abstract}

Key words: Soursop leaves, rice straw, rations, digestion, dry matter, organic matter, in vitro

\begin{abstract}
ABSTRAK
Penelitian ini bertujuan untuk mengetahui dan mengkaji pengaruh penambahan tepung daun sirsak di dalam ransum berbasis jerami padi fermentasi terhadap nilai kecernaan bahan kering dan bahan organik ransum yang dilakukan secara In Vitro. Rancangan penelitian yang digunakan adalah rancangan acak lengkap (RAL) yang terdiri 4 perlakuan dan 4 ulangan. Perlakuan yang dicobakan terdiri : P0 $=$ Ransum basal, $\mathrm{P} 1=\mathrm{P} 0+$ Tepung daun sirsak $1 \%, \mathrm{P} 2=\mathrm{P} 0+$ Tepung daun sirsak $2 \%, \mathrm{P} 3=\mathrm{P} 0+$ Tepung daun sirsak $3 \%$. Ransum basal terdiri Jerami Padi Fermentasi 45\%, Rumput Gajah Mini 30\%, Dedak 10\%, Bungkil Kelapa 10\%, Jagung Giling 4\%, dan Premix 1\%. Peubah yang diamati adalah kecernaan bahan kering (KcBK) dan kecernaan bahan organik (KcBO). Data yang diperoleh dianalisis menggunakan Analisis Ragam dilanjutkan dengan Uji Lanjut Jarak Berganda Duncan (DMRT). Hasil penelitian perlakuan penambahan tepung daun sirsak di dalam ransum berbasis jerami padi fermentasi berpengaruh nyata $(\mathrm{P}<0,05)$ terhadap KcBK dan KcBO. Nilai KcBK dan KcBO tertinggi ditunjukkan oleh perlakuan P3 (3\% Tepung Daun Sirsak) secara berurutan yaitu 60,43\% dan 61,76\%. Kesimpulan dari penelitian ini adalah nilai kecernaan bahan kering dan bahan organik meningkat seiring semakin tinggi penambahan tepung daun sirsak di dalam ransum. Penambahan tepung daun sirsak dalam ransum berbasis jerami padi fermentasi tidak berdampak negatif terhadap kecernaan bahan kering dan bahan organik serta dapat ditambahkan hingga 3\% di dalam ransum.
\end{abstract}

Kata kunci : Daun sirsak, jerami padi, ransum, kecernaan, bahan kering, bahan organik, in vitro

\section{PENDAHULUAN}

Penggunaan bahan pakan alternatif merupakan solusi terbaik untuk mengatasi kelangkaan pakan ternak ruminansia. Selain dapat memaksimalkan pemanfaatan sumberdaya lokal juga dapat memacu kreativitas sehingga menghasilkan produk bahan pakan baru yang bermanfaat untuk memacu pertumbuhan dan produksi ternak. Salah satu bahan pakan alternatif yang dapat digunakan adalah jerami padi fermentasi. Jerami padi fermentasi merupakan hasil pengolahan jerami padi menjadi jerami padi yang kandungan nutrisinya lebih baik dari pada 
sebelum diolah. Proses pengolahan secara fermentasi adalah pengolahan jerami padi dengan cara menambahkan starter mikroba ke dalam jerami padi, kemudian diinkubasi selama 21 hari dalam kondisi anaerob.

Jerami padi fermentasi mengandung nutrisi yang relatif lebih baik dan signifikan meningkatkan protein kasar dan menurunkan kadar serat kasar. Nilai nutrisi jerami padi tanpa fermentasi yaitu bahan organik $73,50 \%$, protein kasar 4,00\%, lemak kasar 1,12\% (Hidayat dan Purnama, 2005), dan serat kasar 32,14\% (Sarwono dan Arianto, 2003). Adapun nilai nutrisi jerami padi fermentasi baik yang difermentasi dengan penambahan starter Starbio Probiotik, Probiotik FM, MOL Bonggol Pisang, maupun Mikrostar LA2 memiliki kisaran nutrisi sebagai berikut: bahan organik 70,59-75,08\%, protein kasar 7,40 - 8,50\%, lemak kasar 1,57 $2,85 \%$, dan serat kasar 18,87 - 19,85\% (Suningsih et al., 2019). Kandungan nutrisi jerami padi fermentasi tersebut tidak jauh berbeda dengan kandungan nutrisi yang dimiliki oleh rumput unggul, seperti rumput gajah yang mengandung nutrisi : bahan organik $88,30 \%$, protein kasar 9,79\%, serat kasar $34,94 \%$ (Munasik et al., 2012). Dengan demikian jerami padi dapat digunakan sebagai pengganti rumput unggul.

Produktivitas ternak ruminansia selain dipengaruhi oleh kandungan nutrisi juga dipengaruhi oleh nilai kecernaan bahan pakan. Nilai kecernaan bahan pakan pada ternak ruminansia salah satunya dipengaruhi oleh aktivitas mikroba seperti Bakteri, Protozoa, dan fungi. Dalam kondisi normal populasi bakteri lebih tinggi daripada protozoa. Menurut McDonald et al. (2011) populasi bakteri rumen mencapai $10^{9} \mathrm{sel} / \mathrm{ml}$, dan protozoa mencapai $10^{6}$ $\mathrm{sel} / \mathrm{ml}$. Bakteri dalam saluran pencernaan berperan sebagai pendegradasi serat kasar. Protozoa berperan sebagai pendegrdasi pati sehingga $\mathrm{pH}$ rumen berada dalam keadaan optimum untuk proses fermentasi bahan pakan. Namun selain sebagai pencerna pati, protozoa memiliki sifat predator atau memakan bakteri, sehingga jika jumlah protozoa tidak dikendalikan maka populasi bakteri akan berkurang yang berdampak pada rendahnya nilai kecernaan bahan pakan. Oleh sebab itu diperlukan suatu bahan yang dapat menekan populasi protozoa (Defaunasi). Bahan tersebut dapat berupa bahan herbal yang memiliki kandungan senyawa fitokimia atau senyawa bioaktif. Menurut Thalib (2008) Saponin merupakan salah satu senyawa defaunasi yang dapat menekan populasi protozoa. Saponin dapat berikatan dengan sterol pada permukaan sel protozoa sehingga membran sel mengalami lisis dan pecah yang mengakibatkan protozoa mati.

Daun sirsakmerupakan salah satu bahan herbal yang banyak mengandung senyawa bioaktif seperti Steroid, Flavonoid, Saponin, dan Tanin. Sebagian besar penggunaan bahan senyawa bioaktif terbukti mempengaruhi dinamika mikroflora, dan fungsi alat pencernaan. Namun mekanisme kerja untuk setiap jenis senyawa bioaktif tersebut berbeda. Senyawa bioaktif secara langsung mampu mengubah atau menstabilkan alat pencernaan (Londok dan Mandey, 2014). Dengan demikian diharapkan penambahan tepung daun sirsak di dalam ransum berbasis jerami padi fermentasi dapat mengoptimalkan proses fermentabilitas bahan pakan di dalam saluran pencernaan secara In Vitro.

Teknik In Vitro merupakan teknik yang dapat digunakan untuk mengukur nilai kecernaan dari suatu bahan pakan. Menurut Suningsih et al.(2017) teknik In Vitro memiliki beberapa kelebihan yaitu jumlah sampel yang digunakan relatif sedikit, biaya yang dikeluarkan lebih murah, dapat menentukan nilai kecernaan berbagai jenis sampel pakan dalam waktu relatif singkat (96 jam). Selain itu proses fermentasi dan aktivitas mikroba di dalam cairan rumen tidak dipengaruhi oleh induk semang.

Penelitian ini bertujuan untuk mengetahui dan mengkaji pengaruh penambahan tepung daun sirsak di dalam ransum berbasis jerami padi fermentasi terhadap nilai kecernaan bahan kering dan bahan organik ransum yang dilakukan secara In Vitro. Manfaat dari penelitian dapat mengetahui perlakuan terbaik dari beberapa perlakuan penambahan tepung daun sirsak di dalam ransum terhadap kecernaan bahan kering dan bahan organik sehingga nantinya dapat diaplikasikan secara In Vivo.

\section{MATERI DAN METODE}

\section{Waktu dan Tempat}

Penelitian ini telah dilaksanakan dari bulan Maret sampai Agustus 2019. Tempat pelaksanakan fermentasi jerami padi dilakukan selama 21 hari di Laboratorium Fakultas Pertanian Universitas Musi Rawas. Analisis Proksimat Sampel dilakukan di Laboratorium PAU IPB Bogor, dan analisis In Vitro dilakukan 
di Laboratorium Nutrisi Ternak Perah Fakultas Peternakan IPB Bogor.

Materi yang digunakan dalam penelitian terdiri atas bahan dan alat. Bahan yang digunakan terdiri : Jerami Padi, Rumput Gajah Mini, Dedak Padi, Jagung Giling, Premix, Tepung Daun Sirsak, Bahan campuran untuk membuat jerami padi fermentasi, MOL Bonggol Pisang, Cairan Rumen, Larutan $\mathrm{McD}$ ougall, $\mathrm{HgCl}_{2}$, Larutan Pepsin, gas $\mathrm{CO}_{2}$. Adapun peralatan yang digunakan diantaranya alat pemotong, kantong plastik, Terpal, Tali rapia, Hand Sprayer, Oven, Blender, Desikator, dan Peralatan untuk analisis In Vitro.

\section{Rancangan Penelitian}

Rancangan penelitian yang digunakan adalah Rancangan Acak Lengkap (RAL) yang terdiri atas 4 Perlakuan dan 4 Ulangan. Perlakuan yang dicobakan terdiri atas : $\mathrm{P} 0=$ Ransum basal, $\mathrm{P} 1=\mathrm{P} 0+$ Tepung daun sirsak $1 \%, \mathrm{P} 2=\mathrm{P} 0+$ Tepung daun sirsak $2 \%, \mathrm{P} 3=\mathrm{P} 0+$ Tepung daun sirsak $3 \%$.

\section{Prosedur Pembuatan Jerami Padi Fermentasi}

Prosedur membuat jerami padi fermentasi menggunakan Starter MOL Bonggol Pisang mengacu kepada hasil penelitian yang telah dilakukan oleh Suningsih et al (2019) yaitu sebagai berikut : Jerami padi berkadar air $\pm 60 \%$ dan berukuran 3-5 $\mathrm{cm}$ disiapkan sebanyak $1 \mathrm{~kg}$. Selanjutnya disiapkan bahan urea $3 \mathrm{~g}$, dedak $5 \mathrm{~g}$, gula $3 \mathrm{~g}$, dan MOL Bonggol pisang sebanyak 2 $\mathrm{ml}$. Urea dan gula dilarutkan ke dalam air sebanyak $250 \mathrm{ml}$. Selanjutnya bahan - bahan tersebut dicampurkan di dalam baskom hingga homogen. Setelah homogen, kemudian dimasukkan ke dalam kantong plastik berukuran $5 \mathrm{~kg}$ dua lapis, diikat menggunakan rapia sambil dimampatkan hingga tidak ada udara. Terakhir, difermentasi selama 21 hari.

\section{Pembuatan Tepung Daun Sirsak}

Prosedur persiapan tepung daun sirsak meliputi pengambilan daun sirsak dari tangkainya. Daun sirsak diambil pada bagian tengah tangkai (5 Lembar). Kemudian dipotong potong untuk memudahkan pengovenan dan penghalusan. Selanjutnya daun sirsak dikeringkan pada suhu $60^{\circ} \mathrm{C}$ selama 24 - 48 jam. Setelah kering, daun sirsak dimasukkan ke dalam Desikator selama 10 - 15 menit. Kemudian digiling menggunakan blender. Selanjutnya, hasil penggilingan di saring sehingga memperoleh ukuran partikel tepung daun sirsak yang sama. Tepung daun sirsak dikemas dan siap digunakan untuk ditambahkan ke dalam ransum. Menurut referensi pada Tabel 1 berikut dapat dilihat hasil analisis proksimat dan skrining fitokimia tepung daun sirsak.

Tabel 1. Hasil analisis proksimat dan skrining fitokimia tepung daun sirsak

\begin{tabular}{lcc}
\hline & Analisis Proksimat \\
\hline Jenis Nutrisi & Kandungan & Satuan \\
\hline Bahan Kering & 87,58 & $\%$ \\
Abu & 8,93 & $\%$ \\
Protein Kasar & 16,90 & $\%$ \\
Serat Kasar & 28,36 & $\%$ \\
Lemak Kasar & 4,76 & $\%$ \\
Beta-N & 28,63 & $\%$ \\
Ca & 2,09 & $\%$ \\
P & 0,35 & $\mathrm{kkal} / \mathrm{kg}$ \\
GE & 4.195 & $\%$ \\
\hline
\end{tabular}

\begin{tabular}{lc}
\multicolumn{1}{c}{ Jenis Metabolit } & Skrining Fitokimia \\
\hline Sekunder & \\
\hline Alkaloid & - \\
Steroid & + \\
Flavonoid & + \\
Tannin & + \\
Saponin & + \\
Tripenoid & - \\
Hydroquinone & -
\end{tabular}

Keterangan : $+=$ Ada, $-=$ Tidak Ada, Sumber : Londok dan Mandey (2014)

\section{Pembuatan Ransum Perlakuan}

Ransum perlakuan disusun berdasarkan kebutuhan nutrien kambing yaitu TDN $60-70 \%$, PK $9-21 \%$ (Permentan, 2014). Metode formulasi ransum yang digunakan adalah metode Trial and Error Method. Bahan pakan yang digunakan terdiri atas jerami padi fermentasi, rumput Gajah Mini, dedak, bungkil kelapa, jagung giling, premix, dan tepung daun sirsak. Penggunaan masing - masing bahan pakan sehingga terbentuk ransum basal terdiri jerami padi fermentasi $45 \%$, rumput gajah mini $30 \%$, dedak $10 \%$, bungkil kelapa $10 \%$, jagung giling $4 \%$, premix $1 \%$. Penambahan tepung daun sirsak dilakukan sesuai perlakuan. Formulasi ransum ini penting dilakukan karena menurut Yanuartono et al. (2017) mengingat jika jerami padi hanya diberikan tunggal ke ternak, maka akan terjadi ketidak seimbangan nutrisi, sehingga perlu dikombinasikan dengan konsentrat. Formula ransum dan kandungan nutrisi ransum perlakuan dapat dilihat pada Tabel 2 berikut : 
Tabel 2. Formulasi dan kandungan nutrisi ransum perlakuan

\begin{tabular}{lcccc}
\hline \multirow{2}{*}{ Bahan Pakan (\%) } & \multicolumn{4}{c}{ Perlakuan } \\
\cline { 2 - 5 } & P0 & P1 & P2 & P3 \\
\hline Jerami Padi Fermentasi & 45 & 45 & 45 & 45 \\
R. Gajah Mini & 30 & 30 & 30 & 30 \\
Dedak & 10 & 10 & 10 & 10 \\
Bungkil Kelapa & 10 & 10 & 10 & 10 \\
Jagung Giling & 4 & 4 & 4 & 4 \\
Premix & 1 & 1 & 1 & 1 \\
Tepung Daun Sirsak & 0 & 1 & 2 & 3 \\
\hline Total & 100 & 101 & 102 & 103 \\
\hline & Kandungan Nutrien $(\%)$ & & \\
\hline Total Digestible Nutrien (TDN)* & 60,07 & 60,46 & 60,85 & 61,25 \\
Protein Kasar (PK) & 10,21 & 10,38 & 10,55 & 10,72 \\
Serat Kasar (SK) & 21,34 & 21,62 & 21,90 & 22,19 \\
\hline Keren
\end{tabular}

Keterangan : P0 = Ransum basal, P1 = P0 + Tepung daun sirsak 1\%, P2 = P0 + Tepung daun sirsak 2\%, P3 = P0 + Tepung daun sirsak 3\%, *TDN berdasarkan perhitungan rumus Hartadi et al (1990) TDN = $37,937-1,018$ SK $-4,886 \mathrm{LK}+0,173 \mathrm{BETN}+1,042 \mathrm{PK}+0,015 \mathrm{SK}^{2}-0,058 \mathrm{LK}^{2}+0,008(\mathrm{SK})$ $(\mathrm{BETN})+0,119(\mathrm{LK})(\mathrm{BETN})+0,038(\mathrm{LK})(\mathrm{PK})+0,0039\left(\mathrm{LK}^{2}\right)(\mathrm{PK})$.

Berdasarkan Tabel 4 terlihat bahwa dari hasil formulasi ransum berbasis jerami padi fermentasi menghasilkan kandungan nutrisi yaitu TDN $60,07-61,25 \%$, PK 10,21 - 10,72\%, SK 21,34 - 22,19\%. Dari hasil formulasi ransum terlihat bahwa semakin tinggi dosis penambahan tepung daun sirsak, maka semakin tinggi pula kandungan nutrisi yang terbentuk.

\section{Pengukuran Kecernaan Bahan Kering dan Bahan Organik secara In Vitro}

Pengukuran kecernaan bahan kering dan bahan organik ransum berbasis jerami padi fermentasi yang diberi penambahan tepung daun sirsak dilakukan secara in Vitro dengan menggunakan metode Tilley dan Terry (1963). Selanjutnya nilai kecernaan bahan kering (KcBK) dan bahan organik $(\mathrm{KcBO})$ ditentukan dengan rumus sebagai berikut :

$$
\begin{aligned}
& \operatorname{KcBK}(\%)=\frac{\text { BK Sampel }(\mathrm{g})-\text { BK Residu }(\mathrm{g})-\text { BK Blanko }}{\text { BK Sampel }(\mathrm{g})} \times 100 \% \\
& \mathrm{KcBO}(\%)=\frac{\text { BO Sampel }(\mathrm{g})-\text { BO Residu }(\mathrm{g})-\text { BO Blanko }}{\text { BO Sampel }(\mathrm{g})} \times 100 \%
\end{aligned}
$$

\section{Analisis Data}

Data yang diperoleh dianalisis menggunakan analisis Ragam (Analyse of Variance). Perlakuan yang berpengaruh nyata terhadap data peubah yang diamati dilakukan uji lanjut menggunakan uji Jarak Berganda Duncan (Duncan Multiple Range Test).

\section{HASIL DAN PEMBAHASAN}

\section{Kecernaan Bahan Kering (KcBK)}

Nilai kecernaan bahan kering ransum berbasis jerami padi fermentasi yang ditambahkan tepung daun sirsak dapat dilihat pada Tabel 3 .

Tabel 3. Kecernaan bahan kering (KcBK) ransum berbasis jerami padi fermentasi dengan penambahan tepung daun sirsak

\begin{tabular}{cccccc}
\hline \multirow{2}{*}{ Perlakuan } & \multicolumn{3}{c}{ Ulangan } & \multirow{2}{*}{ Rataan } \\
\cline { 2 - 4 } & 1 & 2 & 3 & 4 & \\
\hline P0 & 55,59 & 53,11 & 54,15 & 55,38 & $54,56^{\mathrm{a}}$ \\
P1 & 56,43 & 57,29 & 57,21 & 57,64 & $57,14^{\mathrm{b}}$ \\
P2 & 58,88 & 58,90 & 58,54 & 57,82 & $58,54^{\mathrm{b}}$ \\
P3 & 60,77 & 60,96 & 60,93 & 59,04 & $60,43^{\mathrm{c}}$ \\
\hline
\end{tabular}

Keterangan : P0 = Ransum basal, P1 = P0 + Tepung daun sirsak 1\%, P2 = P0 + Tepung daun sirsak 2\%, P3 = P0 + Tepung daun sirsak $3 \%$, Rataan yang diikuti oleh superskrip berbeda pada kolom yang sama menunjukkan perbedaan yang nyata $(\mathrm{P}<0,05)$.

Kecernaan bahan kering menggambarkan seberapa banyak nutrien (kecuali air) yang terkandung dalam ransum yang dapat diserap oleh saluran pencernaan ternak kambing (In 
Vitro). Hasil analisis ragam menunjukkan bahwa perlakuan penambahan tepung daun sirsak dalam ransum berpengaruh nyata terhadap $(\mathrm{P}<0,05)$ KcBK. Hasil uji lanjut Duncan memperlihatkan bahwa perlakuan P1 dan P2 berbeda nyata dengan perlakuan P0 dan P3. Rataan nilai KcBK (Tabel 3) terlihat bahwa nilai kecernaan bahan kering terendah ditunjukkan oleh perlakuan P0 $(54,56 \%)$ dan tertinggi ditunjukkan oleh perlakuan P3 $(60,43 \%)$. Hal ini disebabkan karena kandungan nutrisi terutama serat kasar (karbohidrat komplek) berbeda antara perlakuan yang satu dengan yang lainnya sehingga berdampak pada nilai kecernaan. Hal ini sejalan dengan pernyataan Hartono et al. (2015) bahwa kecernaan berkaitan dengan kandungan kimiawi pakan terutama serat kasar. Menurut Anggorodi (1994) semakin tinggi kandungan serat dalam suatu bahan pakan, maka akan semakin rendah nilai kecernaan bahan pakan tersebut dikarenakan dinding sel bahan semakin tebal sehingga sulit ditembus oleh getah pencernaan. Hal ini berbanding terbalik dengan hasil penelitian ini, dimana nilai kecernaan ransum dalam penelitian ini semakin tinggi seiring dengan peningkatan kandungan serat kasar sebagai akibat dari semakin meningkatnya dosis penambahan tepung daun sirsak dalam ransum (paling tinggi pada P3). Ada beberapa dugaan yang menyebabkan hal tersebut terjadi, pertama kandungan serat kasar hingga level 22,19\% pada perlakuan P3 masih pada taraf yang ditoleransi oleh mikroba yang ada di dalam cairan rumen sehingga proses pencernaan masih berlangsung secara optimal dan menghasilkan nilai kecernaan yang optimal juga. Kedua, kandungan senyawa fitokimia dalam tepung daun sirsak secara tidak langsung membantu mengotimalkan proses pencernaan bahan pakan. Menurut Hapsari et al. (2018) kandungan Saponin dalam ransum diduga dapat menurunkan populasi protozoa sehingga dapat meningkatkan populasi bakteri yang berdampak pada peningkatan kecernaan bahan pakan.

\section{Kecernaan Bahan Organik (KcBO)}

Nilai kecernaan bahan organic ransum berbasis jerami padi fermentasi yang diberi penambahan tepung daun sirsak dapat dilihat pada Tabel 4.

Bahan organik merupakan seluruh zat makanan (Karbohidrat, Protein, Lemak, dan Vitamin) kecuali air dan abu atau mineral. Kecernaan bahan organik adalah banyaknya zat zat makanan tersebut yang dapat dicerna oleh saluran pencernaan ternak kambing. Menurut Setiyaningsih et al. (2012) menyatakan bahwa bahan organik merupakan zat - zat yang terkandung dalam bahan kering sehingga faktor faktor yang mempengaruhi tinggi rendahnya kecernaan bahan kering akan mempengaruhi tinggi rendahnya kecernaan bahan organik dalam suatu ransum atau pakan.

Hasil analisis ragam perlakuan penambahan tepung daun sirsak dalam ransum kambing berbasis jerami padi fermentasi berpengaruh nyata $(\mathrm{P}<0,05)$ terhadap $\mathrm{KcBO}$. Hasil uji lanjut Jarak Berganda Duncan memperlihatkan bahwa perlakuan P1 dan P2 berbeda nyata dengan perlakuan P0 dan P3. Nilai kecernaan bahan organik terendah ditunjukkan oleh perlakuan P0 $(55,26 \%)$ dan tertinggi ditunjukkan oleh perlakuan P3 $(61,76 \%)$. Hal ini disebabkan penambahan tepung daun sirsak hingga $3 \%$ di dalam ransum meningkatkan kandungan nutrisi terutama bahan organic sehingga menghasilkan nilai kecernaan bahan organik yang tinggi pula.

Tabel 4. Kecernaan bahan organik $(\mathrm{KcBO})$ ransum berbasis jerami padi fermentasi dengan penambahan tepung daun sirsak

\begin{tabular}{|c|c|c|c|c|c|}
\hline \multirow{2}{*}{ Perlakuan } & \multicolumn{4}{|c|}{ Ulangan } & \multirow{2}{*}{ Rataan } \\
\hline & 1 & 2 & 3 & 4 & \\
\hline P0 & 56,02 & 53,48 & 55,08 & 56,46 & $55,26^{\mathrm{a}}$ \\
\hline P1 & 57,17 & 58,07 & 58,14 & 58,32 & $57,92^{\mathrm{b}}$ \\
\hline P2 & 59,98 & 60,08 & 59,67 & 58,41 & $59,53^{b}$ \\
\hline P3 & 62,00 & 62,64 & 62,34 & 60,07 & $61,76^{\mathrm{c}}$ \\
\hline
\end{tabular}

Keterangan : P0 = Ransum basal, P1 = P0 + Tepung daun sirsak 1\%, P2 = P0 + Tepung daun sirsak 2\%, P3 = P0 + Tepung daun sirsak $3 \%$, Rataan yang diikuti oleh superskrip berbeda pada kolom yang sama menunjukkan perbedaan yang nyata $(\mathrm{P}<0,05)$.

Diketahui bahwa Jerami padi yang digunakan dalam penelitian ini merupakan jerami padi hasil fermentasi. Jerami padi fermentasi memiliki kandungan bahan organik yang lebih baik dibandingkan dengan jerami padi tanpa fermentasi. Hasil penelitian Suningsih et al 
(2019) menunjukkan bahwa kandungan protein kasar jerami padi fermentasi meningkat dari 4,00\% menjadi $8,50 \%$, Lemak Kasar $1,12 \%$ menjadi $2,85 \%$, dan serat kasar menurun dari $32,14 \%$ menjadi $18,87 \%$. Penurunan serat kasar mampu meningkatkan kecernaan bahan organic. Selain memiliki kandungan nutrisi yang lebih baik, jerami padi fermentasi juga memliki kualitas kecernaan yang lebih baik dibandingkan jerami padi tanpa fermentasi. Menurut Haryanto (2003) perlakuan fermentasi jerami padi menggunakan probiotik dan urea dapat meningkatkan daya cerna dari $28-30 \%$ menjadi 50-55\%. Selanjutnya menurut Harfiah dan Mide (2014) kecernaan bahan kering dan bahan organik jerami padi fermentasi baik dengan penambahan alkali, bakteri asam laktat, jamur, maupun mineral sulfur signifikan lebih tinggi dibandingkan kecernaan jerami padi tanpa fermentasi.

Pola kecernaan bahan organik selalu mengikuti pola kecernaan bahan kering. Dengan demikian ketika kecernaan bahan kering semakin tinggi maka kecernaan bahan organik juga akan semakin tinggi. Hal ini sejalan dengan hasil penelitian Suningsih et al. (2017) bahwa pola kecernaan bahan organik sama dengan pola kecernaan bahan kering.

\section{KESIMPULAN}

Dari penelitian ini dapat disimpulkan penambahan tepung daun sirsak dalam ransum berbasis jerami padi fermentasi signifikan mempengaruhi kecernaan bahan kering dan bahan organik ransum secara In Vitro. Nilai kecernaan bahan kering dan bahan organik meningkat seiring semakin tinggi penambahan tepung daun sirsak di dalam ransum. Penambahan tepung daun sirsak dalam ransum berbasis jerami padi fermentasi tidak berdampak negatif terhadap kecernaan bahan kering dan bahan organik serta dapat ditambahkan hingga $3 \%$ di dalam ransum.

\section{UCAPAN TERIMAKASIH}

Terimakasih penulis sampaikan kepada Ditjen Penguatan Riset dan Pengembangan Kementerian Riset, Teknologi, dan Pendidikan Tinggi atas pendanaan penelitian, skema Penelitian Dosen Pemula dengan No. SK. 7/E/KTP/2019 tanggal 19 Februari 2019 yang telah diberikan. Terimakasih juga disampaikan kepada LPPM Universitas Musi Rawas yang telah membantu berjalannya proses penelitian sehingga dapat berjalan dengan baik.

\section{DAFTAR PUSTAKA}

Anggorodi. 1994. Ilmu Makanan Ternak Umum. Penerbit Gramedia. Jakarta.

Harfiah dan M. Z. Mide. 2014. Kecernaan In Vitro jerami padi hasil perlakuan kombinasi alkali, fermentasi dengan mikroba selulolitik, lignolitik dan asam laktat yang disuplemetasi dengan sulfur. JITP. 3 (3) : $96-100$

Hapsari, N. S., D. W. Harjanti, dan A. Muktiani. 2018. Fermentabilitas pakan dengan imbuhan ekstrak daun babadotan (Ageratum conyzoides) dan Jahe (Zingiber officinale) pada Sapi Perah Secara In Vitro. Agripet: 18 (1): 1-9

Hartono, R., Y. Fenita dan E. Sulistyowati. 2015. Uji In Vitro Kecernaan Bahan Kering, Bahan Organik dan Produksi $\mathrm{N}_{-} \mathrm{NH}_{3}$ pada Kulit Buah Durian (Durio zibethinus) yang Difermentasi Jamur Tiram Putih (Pleurotus ostreatus) dengan Perbedaan Waktu Inkubasi. Jurnal Sain Peternakan Indonesia. 10 (2) : 87-94

Haryanto, B. 2003. Jerami padi fermentasi sebagai ransum dasar ruminansia. Warta Penelitian dan Pengembangan Pertanian. 25 (3) : 1-2.

Hidayat dan D. R. Purnama. 2005. Pemanfaatan Jerami Padi Fermentasi sebagai Pakan Penggemukkan Sapi PO di Kecamatan Banyu Resmi Kabupaten Garut. Prosiding Temu Teknik Nasional Tenaga Fungsional Pertanian : 26-30.

Londok J. J.M.R. dan J. S. Mandey. 2014. Potensi Fitokimia dan Aktivitas Antimikroba Daun Sirsak (Annona Muricata Linn.) sebagai Kandidat Bahan Pakan Ayam Pedaging. Jurnal LPPM Bidang Sain dan Teknologi. 1 (1): 30-36

Mc. Donald, P., R. A. Edwards, dan J. F. D. Greenhalg. 2011. Animal Nutrition, Fourth Edition, Longman London and New York. 
Munasik M, C. L. Sutrisno, S. Anwar, C. H. Prayitno. 2012. The growth, yield and quality of elephant grass (Pennisetum purpureum) spesific tolerant of acid soils by mutagenesis of ethylmethana sulfonate. Anim Prod. 14:87-91.

Permentan. 2014. Peraturan Menteri Pertanian Republik Indonesia Nomor 102/Permentan/OT.140/7/2014 Tentang Pedoman Pembibitan Kambing dan Domba yang Baik. http://perundangan.pertanian.go.id/admin $/$ p_mentan/Permentan\%20No.102\%20Ta hun\%202014\%20Pembibitan\%20Kambi ng.pdf. (Diakses tanggal 4 April 2019)

Suningsih, N, S. Novianti dan J. Andayani. 2017. Level Larutan McDougall dan Asal Cairan Rumen pada Teknik In Vitro. Jurnal Sain Peternakan Indonesia. 12 (3) : $341-352$.

Suningsih, N, W. Ibrahim, O. Liandris, R. Yulianti. 2019. Kualitas Fisik dan Nutrisi Jerami Padi Fermentasi pada Berbagai Penambahan Starter. Jurnal Sain Peternakan Indonesia. 14 (2) : 191 - 200
Sarwono, B. dan H. B. Arianto. 2003. Penggemukkan Sapi Potong secara Cepat. Penerbit Swadaya : Jakarta

Setiyaningsih, K.D., M. Christiyanto dan Sutarno. 2012. Kecernaan bahan kering dan bahan organik secara in vitro hijauan Desmodium cinereum pada berbagai dosis pupuk organik cair dan jarak tanam. Animal Agriculture Journal. 1(2) : 51 63.

Thalib, A. 2008. Buah Lerak mengurangi gas metan pada Hewan Ruminansia. Warta Penelitian dan Pengembangan Pertanian. 30 (2) : 11-12.

Tilley, J.M.A. dan Terry, R.A. 1963. A two stage technique for the in vitro digestion of forage.J. British Grassland Soc. 18:104111.

Yanuartono, H. Purnamaningsih, S. Indarjulianto dan A. Nururrozi. 2017. Potensi jerami sebagai pakan ternak ruminansia. Jurnal Ilmu-Ilmu Peternakan. 27 (1) : 40 - 62. 